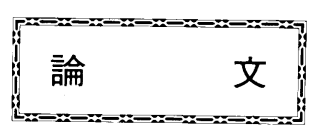

\title{
液晶バックライト用低圧 $\mathrm{Ar}-\mathrm{Hg}$ 放電中の粒子密度と プラズマパラメータ
}

\author{
正会員 後 藤 みき(神奈川工科大学) \\ 正会員大谷清 (神奈川工科大学) \\ 非会員 酒 井隆 行 (神奈川工科大学)
}

\section{Particle Densities and Plasma Parameters in the Low-Pressure Ar-Hg Discharge Used for Liquid Crystal Display Backlighting}

Member Miki Goto (Kanagawa Institute of Technology),

Non Member Takayuki Sakai (Kanagawa Institute of Technology),

Member Kiyoshi Ohtani (Kanagawa Institute of Technology) and

Member Toshihiko Arai (Kanagawa Institute of Technology)

\begin{abstract}
The electron temperature and electron density in the tube axis of a low-pressure Ar-Hg discharge lamp with 4-mm inner diameter were measured under various bath temperatures using a probe method. The electron temperature decreased from 2 to $1 \mathrm{eV}$ in bath temperature region from 0 to $80^{\circ} \mathrm{C}$. The electron density had a minimum at about $50^{\circ} \mathrm{C} . \mathrm{The} \mathrm{Hg}^{+} \mathrm{ion}, \mathrm{Hg}$ metastable, and Ar metastable densities were measured using a modified absorption method. The $\mathrm{Hg}$ ion and $\mathrm{Hg} 6 \mathrm{p}^{3} \mathrm{P}_{0,2}$ densities increased with bath temperature and saturated above $60^{\circ} \mathrm{C}$. The $\mathrm{Hg}$ molecular ion density was determined by combining the modified absorption and probe methods. The $\mathrm{Hg}$ ionization rate caused by Penning ionized collisions between Ar metastables and $\mathrm{Hg}$ atoms was maximum at about $30^{\circ} \mathrm{C}$.
\end{abstract}

KEYWORDS : particle densities, plasma parameters, Ar-Hg discharge, LCD backlighting, positive column

\section{1.はじめに}

従来, 比較的大きな管径である一般の蛍光ランプ $(d=36 \mathrm{~mm})^{1)-3)}$

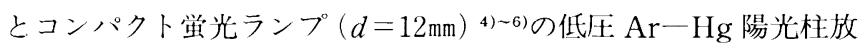
電については多くの研究が行われ, 電離機構についてはかなり理 解されている.

一方最近は液晶ディスプレイのバックライトとして管径が 2 〜 $6 \mathrm{~mm}$ と細い蛍光ランプが使用されている. バックライトユニッ トは薄型の傾向にあるためバックライトも高輝度細管化が望まれ ている。しかしその蛍光ランプについての物性的研究はまだほと んど行われていない.

蛍光ランプの最適水銀蒸気压付近では階段電離が主要な過程と 考えられるので，細い管径の蛍光ランプと $36 \mathrm{~mm}$ 管との相似則が厳 密に成り立たない可能性がある。また細い管径の蛍光ランプでは $\mathrm{Hg}$ ( I ) $253.7 \mathrm{~nm}$ 線強度の最大となる水銀蒸気圧は一般の蛍光亏 ンプの場合より高くなる7). それ故細い管径の蛍光ランプの電離 機構を定量的に解明するには, 各種パラメー夕を直接測定し直し, 解析を行う必要があると思われる。

本研究では管径 $4 \mathrm{~mm}$ の液晶バックライト用 $\mathrm{Ar}-\mathrm{Hg}$ プラズマ において改良型吸収法 ${ }^{8)}$ 有いて管軸上の水銀イオン基底準位密
度9) と水銀準安定原子密度㧍よびアルゴン準安定原子密度を测定 した。またプローブ法を用いて電子温度と電子密度及び電界強 度 ${ }^{10)}$ を測定した。それらの測定結果を報告するとともに水銀の電 離機構の検討を行った。

\section{2. 実験方法}

図 1 は水銀の重要な準位と吸収法で用いたスペクトル線の波長 を示したエネルギー準位図である。吸収測定に用いた波長は水銀 イオン基底準位密度には $194.2 \mathrm{~nm}\left(6 \mathrm{p}^{2} \mathrm{P}_{1 / 2} \rightarrow 6 \mathrm{~s}^{2} \mathrm{~S}_{1 / 2}\right)$, 水銀準安定 原子密度には404.7, 435.8, $546.1 \mathrm{~nm}\left(7 \mathrm{~s}^{3} \mathrm{~S}_{1} \rightarrow 6 \mathrm{p}^{3} \mathrm{P}_{0,1,2}\right)$, アルゴ ン準安定原子密度には696.5nm $\left(4 \mathrm{p}^{3} \mathrm{P} \rightarrow 4 \mathrm{~s}^{3} \mathrm{P}_{2}\right)$ を用いた。

図 2 は改良型吸収法による粒子密度の測定装置の概略困を示 卞. 放電管は内径 $4 \mathrm{~mm}$ の石英製である. 改良型吸収法の原理 ${ }^{8}$ に基 づき，1つのアノード A とプラズマ長 $l$ を変えられるように $2 つ$ のカソード $\mathrm{C} 1, \mathrm{C} 2$ が取り付けてある. Arの封入圧力は 3Torr $(400 \mathrm{~Pa})$ ，放電電流は $20 \mathrm{~mA}$ である。水銀蒸気压は放電管全体を 水槽の中に入れ，水温を変化させることにより制御した．陽光柱 放電から放射されるエンドライト強度はアパーチャ $1 （ \varphi=0.4$ $\mathrm{mm})$, チョッパ, アパーチャ $2(\varphi=0.4 \mathrm{~mm})$, レンズ, モノクロメ 一夕(陽光柱放電の約 $0.9 \mathrm{~mm}$ 径の領域からの放射光が入力スリット へ入射)，光電子増倍管，ロックインアンプを用いて測定した。ま ず最初に $\mathrm{A}-\mathrm{C} 1$ 間 (プラズマ長 $l=3 \mathrm{~cm}$ ) で放電させたとき，放射 


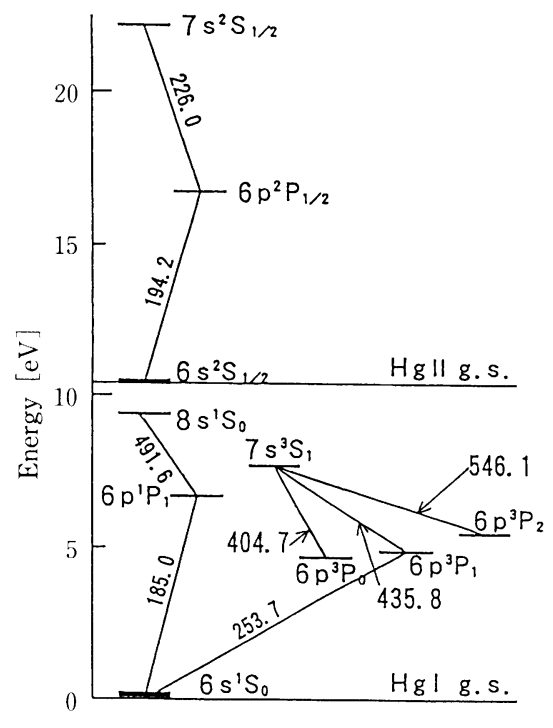

図 1 水銀のエネルギー準位図と吸収法に用いたスペクトル線

Fig. 1 Energy level of $\mathrm{Hg}$ and lines used for the absorption measurement.

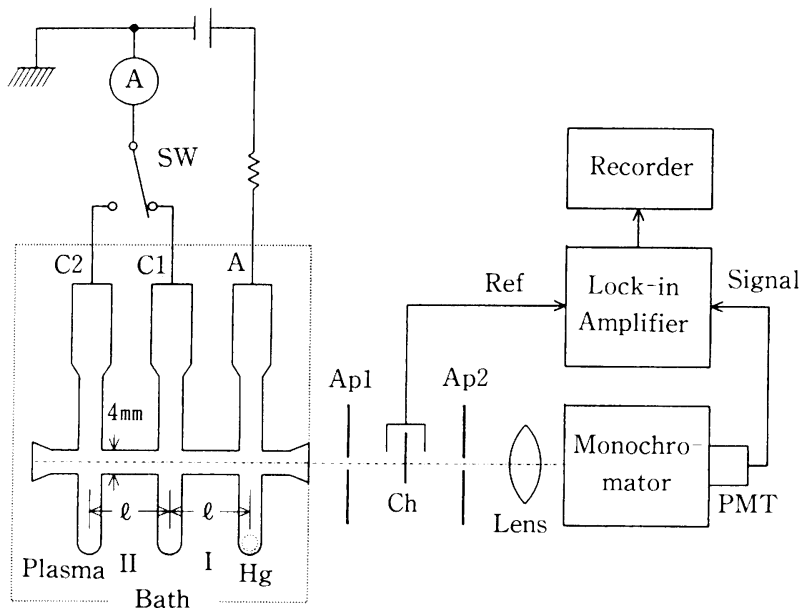

図 2 吸収測定系の概略図

$\mathrm{Ap} 1$ と Ap2：同一のアパーチャ, A：陽極, C1と C2：同一の陰極, PMT : 光電子増倍管

Fig. 2 Schematic diagram of the experimental arrangements for the modified absorption measurement. Ap1 and Ap2: apertures; A : anode ; $\mathrm{C} 1$ and $\mathrm{C} 2$ : identical cathodes; PMT : photomultiplier tube.

される波長 $\lambda$ の水銀線のエンドライト強度 $I_{1}$ を測定する. 次にス イッチを切り換え, $\mathrm{A}-\mathrm{C} 2$ 間 $(2 l=6 \mathrm{~cm})$ で放電させたとき, 同じ 線のエンドライト強度 $I_{2}$ を測定する.このときエンドライト強度 の比は次式のように吸収割合 $G\left(k_{0} l\right)$ の関数で与えられる.

$I_{2} / I_{1}-1=G\left(k_{0} l\right)$

$$
=\frac{\int\left[1-\exp \left(-k_{0} l f_{\nu}\right)\right] \exp \left(-k_{0} l f_{\nu}\right) \mathrm{d} \nu}{\int\left[1-\exp \left(-k_{0} l f_{\nu}\right)\right] \mathrm{d} \nu}
$$

ここで $f_{\nu}$ は波長 $\lambda$ のプロファイルを与える関数である. 水銀はい くつかの同位元素を含むので，Hg (II) 194.2nm 線の場合のプロ ファイルは, 図3(a)に示すような形をしている4). $k_{0}$ は $\mathrm{Hg}^{202}$ の成 分の中心波長に扔ける吸収係数である。各成分のプロファイルが Ar 3Torr および管壁温度によって決まるVoigt 関数で与えられ

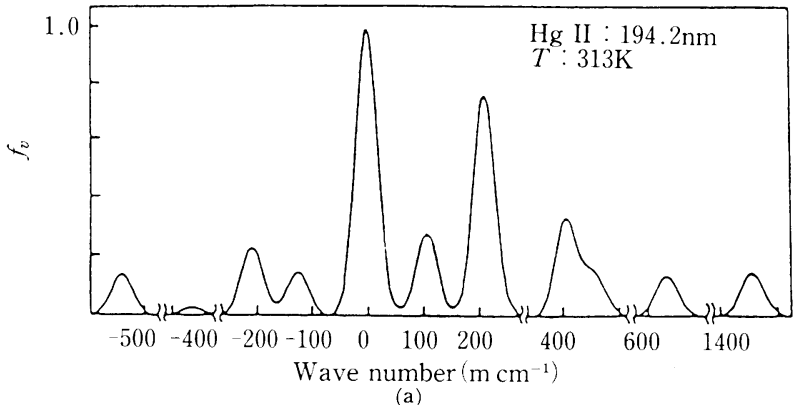

(a)

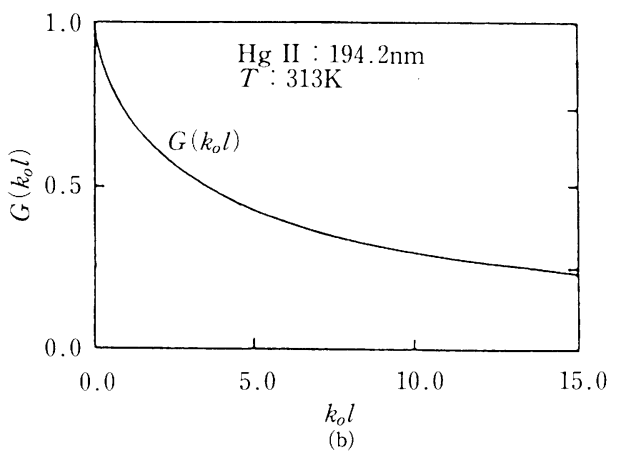

図 3 水銀線のプロファイルと吸収割合

(a) $313 \mathrm{~K}$ における $\mathrm{Hg}$ ( II) $194.2 \mathrm{~nm}$ 線のプロファイル (b) $k_{0} l$ の関数としてホした吸収割合.

Fig. 3 Profile of the $\mathrm{Hg}$ line and absorption rate.

(a) Profile of the $\mathrm{Hg}$ ( II ) $194.2 \mathrm{~nm}$ line at $313 \mathrm{~K}$

(b) $G\left(k_{0} l\right)$ as a function of $k_{0} l$.

ると考え, $k_{0} l$ の関数として $G\left(k_{0} l\right)$ を数值的に計算すると, 図 3 (b)に示寸ような曲線が得られる ${ }^{4)}$. 一方，吸収係数 $k_{0} l$ とそれに対 応寸る遷移の下準位に励起されている原子やイオン密度 $n$ との 間に次の関係がある ${ }^{9)}$

$$
n=\frac{\Delta \nu_{0}}{2}\left(\frac{\pi}{\ln 2}\right)^{\frac{1}{2}} \frac{8 \pi}{\lambda^{2}} \frac{g_{1}}{g_{2}} \frac{1}{A_{21} l} k_{0} l\left(\mathrm{~cm}^{-3}\right)
$$

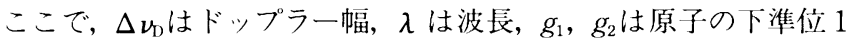
及び上準位 2 の統計的重み， $A_{21}$ は上準位 2 から下準位 1 への遷 移確率である。エンドライト強度比の測定から，図 $3(\mathrm{~b})$ を使って $k_{0} l$ を知り，その值を式(2)へ代入して $n$ を求めることができる. 式 (2)から計算した水銀イオン基底準位密度 $n\left(\mathrm{Hg}^{+}\right)$と $k_{0} l$ の関係式 は次式で示され, 水銀イオン基底準位密度を求めることができる.

$n\left(\mathrm{Hg}^{+}\right)=2.19 \times 10^{11} k_{0} l\left(\mathrm{~cm}^{-3}\right) \cdots \cdots \cdots \cdots \cdots \cdots \cdots \cdots \cdots \cdots \cdots \cdots \cdots \cdots \cdots \cdots \cdots \cdots \cdots \cdots$

水銀の各準安定原子 $\left(6 \mathrm{p}^{3} \mathrm{P}_{0,1,2}\right)$ 密度とアルゴン準安定原子 $\left(4 \mathrm{~s}^{3} \mathrm{P}_{2}\right)$ 密度は水銀イオン基底準位密度を求めた手順で決定し た。それらの密度と $k_{0} l$ の関係式は $n\left(6 \mathrm{p}^{3} \mathrm{P}_{0}\right)=2.22 \times 10^{11} k_{0} l$ $\left(\mathrm{cm}^{-3}\right), \quad n\left(6 \mathrm{p}^{3} \mathrm{P}_{1}\right)=2.36 \times 10^{11} k_{0} l \quad\left(\mathrm{~cm}^{-3}\right), \quad n\left(6 \mathrm{p}^{3} \mathrm{P}_{2}\right)=1.12 \times$ $10^{11} k_{0} l\left(\mathrm{~cm}^{-3}\right), n\left(\mathrm{Ar}^{*}\right)=3.87 \times 10^{11} k_{0} l\left(\mathrm{~cm}^{-3}\right)$ で与えられる.

この吸収法は空の透過率等に依存しないため紫外線の場合でも 正確な吸収測定が可能である。なお $\mathrm{Ar}-\mathrm{Hg}$ 放電プラズマ中の水 銀蒸気圧の一様性については，自己吸収のほとんどない $\mathrm{Hg}$ (II) $226.0 \mathrm{~nm}$ 線 $\left(7 \mathrm{~s}^{2} \mathrm{~S}_{1 / 2} \rightarrow 6 \mathrm{p}^{2} \mathrm{P}_{1 / 2}\right)$ のエンドライト強度の比 $I_{2} / I_{1}-1$ ○となることから確認した.

アルゴンイオン密度 $n\left(\mathrm{Ar}^{+}\right)$は，生成過程として電子衝突によ クアルゴンの中性原子，準安定原子からのイオン化，消滅過程と して主に管壁における再結合を考えると、レート方程式から次式 で与えられる。

$n\left(\mathrm{Ar}^{+}\right)=\tau_{1}\left(n_{\mathrm{Ar}} n_{\mathrm{e}} S_{1}+n_{\mathrm{Arm}} n_{\mathrm{e}} M_{1}\right)$ $(4)$ 
ここで $n_{\mathrm{Ar}}, n_{\mathrm{Arm}}$ はアルゴンの中性基底準位密度, 準安定準位密 度, $n_{\mathrm{e}}$ は $\mathrm{Ar}-\mathrm{Hg}$ 放電中の電子密度, $S_{1}, M_{1}$ は電子衝突によるア ルゴンの中性基底準位, 準安定準位からのイオン化レートで電子 温度に依存する。元はアルゴンイオンの寿命である。一方 $\operatorname{Ar}(\mathrm{I})$ $696.5 \mathrm{~nm}$ 線 $\left(4 \mathrm{p}^{3} \mathrm{P} \rightarrow 4 \mathrm{~s}^{3} \mathrm{P}_{2}\right)$ の上準位 $\left(4 \mathrm{p}^{3} \mathrm{P}\right)$ の密度 $n_{\mathrm{Ar} 1}$ はレート 方程式から次式で与えられる.

$n_{\mathrm{Arl}}=\tau_{2}\left(n_{\mathrm{Ar}} n_{\mathrm{e}} S_{2}+n_{\mathrm{Arm}} n_{\mathrm{e}} M_{2}\right)$

ここで $S_{2}, M_{2}$ は電子衝突によるアルゴンの中性基底準位, 準安定 準位からの励起レート， $\tau_{2}$ は $\operatorname{Ar}\left(4 \mathrm{p}^{3} \mathrm{P}\right)$ 準位の寿命である。なお 高準位からのカスケード過程は無視してある. $\mathrm{Ar}-\mathrm{Hg}$ 放電中に おいて $n_{\mathrm{Ar}}$ が一定で, 電子温度, 電子密度が管壁温度の増加ととも に低下古れば，式(4)，(5)の第 1，2 項とも減少する． $S_{1}$ と $S_{2}, M_{1}$ と $M_{2}$ が同様な変化をするものと仮定するとアルゴンイオン密度 は $\operatorname{Ar}(\mathrm{I}) 696.5 \mathrm{~nm}$ 線の発光強度の管壁温度に対する変化にほぼ 比例するとみなすことができる。よってアルゴンイオン密度は放 電管の管壁から放射される $\mathrm{Ar}$ ( I ) 696.5nm 線のサイドライト強 度を用いて評価した。

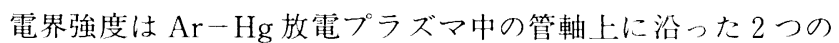
プローブ間の電位差より求めた。管軸上の電子温度と電子密度は シングルプローブ法10)で測定した．陽光柱に挿入した円筒プロー ブは, 半径 $4.3 \times 10^{-3} \mathrm{~cm}$, 長さ $0.1 \mathrm{~cm}$, 表面積 $S=2.7 \times 10^{-3} \mathrm{~cm}^{2}$ であ る.したがって電子の平均自由行程はプローブ半径より大きいの で低ガス压力の場合の電子密度 $n_{\mathrm{e}}$ は次式で与えられ，この式を用 いて求めた。

$$
n_{\mathrm{e}}=\frac{4}{e S}\left(\frac{\pi m_{\mathrm{e}}}{8 k}\right)^{\frac{1}{2}} \frac{I_{\mathrm{pS}}}{\sqrt{T_{\mathrm{e}}}}=1.4 \times 10^{14} \frac{I_{\mathrm{ps}}}{\sqrt{T_{\mathrm{e}}}}\left(\mathrm{cm}^{-3}\right)
$$

ここで, $m_{\mathrm{e}}$ は電子の質量, $e$ は電子の電荷, $k$ はボルツマン定数, $I_{\mathrm{PS}}$ はプローブの飽和電子電流， $T_{\mathrm{e}}$ は電子温度である.

\section{3. 実験結果と考察}

測定した $4 \mathrm{~mm}$ 管の管軸上の電界強度 $E$ と電子温度 $T_{\mathrm{e}}$ の温度 （水銀蒸気圧）依存性を図 4 に示す。電界強度は $50^{\circ} \mathrm{C}$ 付近でピー クを示し，その後管壁温度と共に減少している。電子温度は管壁 温度 $0{ }^{\circ} \mathrm{C}$ か $80^{\circ} \mathrm{C}$ 範囲で $2 \mathrm{eV}$ から $1 \mathrm{eV}$ へと減少している. これら電界強度と電子温度の相対変化は $36 \mathrm{~mm}$ 管で得られた結果 ${ }^{11}$ とほぼ同じであるが, 電子温度の值は $36 \mathrm{~mm}$ 管のものより約 2 倍大 きくなっている。

図 5 はプローブ法で測定した $4 \mathrm{~mm}$ 管の電子密度 $n_{\mathrm{e}}$ と改良型吸 収法で測定した水銀イオン基底準位密度 $n\left(\mathrm{Hg}^{+}\right)$および $\mathrm{Ar}(\mathrm{I})$ $696.5 \mathrm{~nm}$ 線の発光強度 (アルゴンイオン密度 $n\left(\mathrm{Ar}^{+}\right)$) の温度 (水 銀蒸気圧) 依存性を示す。電子密度は $50^{\circ} \mathrm{C}$ 付近で最小を示してい る. 水銀イオン基底準位密度は管壁温度と共に増加し $60^{\circ} \mathrm{C}$ 付近の 高温側で飽和の傾向を示している. $\mathrm{Ar}-\mathrm{Hg}$ 放電プラズマ中の電 子密度 $n_{\mathrm{e}}$ は次式で与えられる。

$n_{\mathrm{e}}=n\left(\mathrm{Ar}^{+}\right)+n\left(\mathrm{Hg}^{+}\right)+n$,

ここで $n$ は水銀イオン基底準位密度以外のイオン密度である. $0{ }^{\circ} \mathrm{C}$ において水銀イオン基底準位密度はほとんど無視できる程小 さいのでアルゴンイオン密度 $n\left(\mathrm{Ar}^{+}\right)$は電子密度 $n_{\mathrm{e}}$ の測定值 $\left(5 \times 10^{11} \mathrm{~cm}^{-3}\right)$ にほほ等しくなる。管壁温度 $0{ }^{\circ} \mathrm{C}$ から $50^{\circ} \mathrm{C}$ の領域 では測定された電子温度, 電子密度が減少することから, 式(4), (5)よりアルゴンイオン密度, $\operatorname{Ar}($ I $) 696.5 \mathrm{~nm}$ 線強度は両方とも減 少する. 式(4)，(5)の $S_{1}$ と $S_{2}, M_{1}$ と $M_{2}$ が同様な変化をすると仮定 すると, $\operatorname{Ar}($ I ) 696.5nm 線強度の管壁温度に対する変化はアルゴ ンイオン密度の変化にほぼ比例するとみなすことができる。した

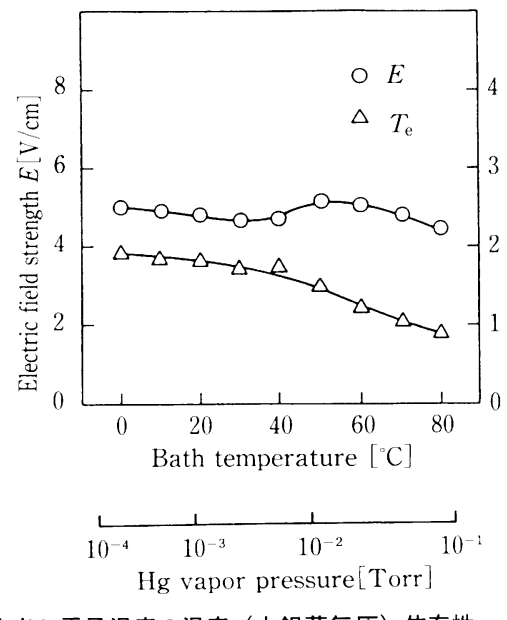

図 4 電界強度と電子温度の温度（水銀蒸気圧）依存性

Fig. 4 Bath temperature ( $\mathrm{Hg}$ vapor pressure) dependence of the electric field strength and the electron temperature.

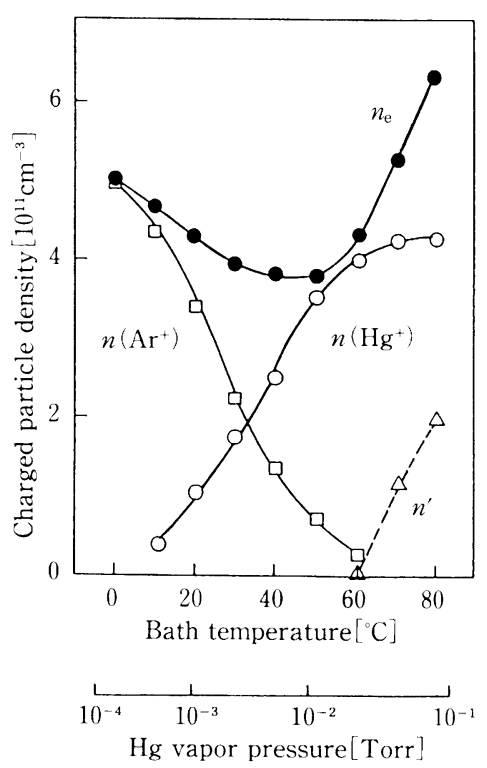

図 5 電子密度と水銀イオン基底原子密度およびアルゴン $696.5 \mathrm{~nm}$ 線強度 $n^{\prime}\left(\mathrm{Ar}^{+}\right)$の温度（水銀蒸気圧）依存性

Fig. 5 Bath temperature ( $\mathrm{Hg}$ vapor pressure) dependence of the electron density, the $\mathrm{Hg}^{+}$ground state ion density and the $\operatorname{Ar}(\mathrm{I}) 696.5 \mathrm{~nm}$ line intensity (Ar ion density).

がってアルゴンイオン密度は $\operatorname{Ar}(\mathrm{I}) 696.5 \mathrm{~nm}$ 線強度と管壁温度 $0{ }^{\circ} \mathrm{C}$ ときの電子密度を用いて次式から求めた.

$$
n\left(\mathrm{Ar}^{+}\right)=n_{\mathrm{eo}} \frac{I_{\mathrm{Ar}}}{I_{\mathrm{Aro}}}
$$

ここで $n_{\mathrm{e} o}, I_{\mathrm{Aro}}$ は管壁温度 $0{ }^{\circ} \mathrm{C}$ における電子密度と $\mathrm{Ar}(\mathrm{I}) 696.5$ $\mathrm{nm}$ 線強度， $I_{\mathrm{Ar}}$ は任意の管壁温度に打ける $\mathrm{Ar}(\mathrm{I}) 696.5 \mathrm{~nm}$ 線強 度である。式(8)から求めた $n\left(\mathrm{Ar}^{+}\right)$の值を確認するため，管壁温 度 $0{ }^{\circ} \mathrm{C}$ から $50^{\circ} \mathrm{C}$ の領域で $n_{\mathrm{e}}$ と $n\left(\mathrm{Hg}^{+}\right)$の差から $n\left(\mathrm{Ar}^{+}\right)$の值を求

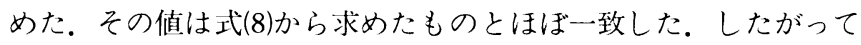
式(8)が近似的に成り立つことを示している. $60^{\circ} \mathrm{C}$ 以上では $n\left(\mathrm{Ar}^{+}\right)$は小さく無視できるので， $n_{\mathrm{e}}$ は次式で示される. 


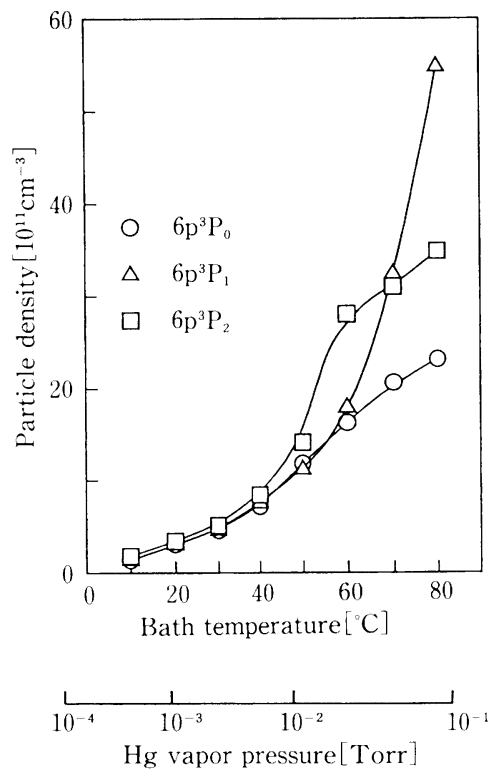

図6 水銀 $6 \mathrm{p}^{3} \mathrm{P}_{0,1,2}$ 密度の温度（水銀蒸気圧）依存性

Fig. 6 Bath temperature ( $\mathrm{Hg}$ vapor pressure) dependence of the $\mathrm{Hg} 6 \mathrm{p}^{3} \mathrm{P}_{0,1,2}$ state densities.

$n_{\mathrm{e}}=n\left(\mathrm{Hg}^{+}\right)+n$

図 5 の破線は $n_{\mathrm{e}}-n\left(\mathrm{Hg}^{+}\right)=n$ をを示す。水銀蒸気圧が高いと き, 次式のような反伈により水銀分子イオンが多く作られる ${ }^{3)}$.

$\mathrm{Hg}^{+}+\mathrm{Hg}\left(6 \mathrm{~s}^{1} \mathrm{~S}_{0}\right)+\mathrm{e} \rightarrow \mathrm{Hg}_{2}{ }^{+}+\mathrm{e}$ ..(10) したがって, n'は主に水銀分子イオン密度 $n\left(\mathrm{Hg}_{2}{ }^{+}\right)$であると考え られる。

電子密度の最小値を示寸管壁温度は $36 \mathrm{~mm}$ 管 ${ }^{11}$ と比較して約 $20^{\circ} \mathrm{C}$ 高温側にずれている。これは管径が細くなることにより，管壁へ の電子の損失が増加するため, 電子温度が高くなり, アルゴン原 子との電子衝突による電離が増加し, アルゴンイオンは高温側ま で存在することによると考えられる.

図 6 は改良型吸収法で測定した水銀 $6 \mathrm{p}^{3} \mathrm{P}_{0,1,2}$ 準安定原子密度の 温度 (水銀蒸気圧) 依存性を示寸。水銀 $6 \mathrm{p}^{3} \mathrm{P}_{0,1,2}$ 淮安定原子密度は それぞれ管壁温度の増加とともに増加し，水銀 $6 \mathrm{p}^{3} \mathrm{P}_{0,2}$ 準位密度は $36 \mathrm{~mm}$ 管, $12 \mathrm{~mm}$ 管のもの ${ }^{2,5)}$ 上り約 $20^{\circ} \mathrm{C}$ 高温側で飽和の傾向を示して いる. 高温側での準安定原子密度の大きさは $n\left(\mathrm{Hg}^{3} \mathrm{p}^{3} \mathrm{P}_{1}\right)>$ $n\left(\mathrm{Hg}_{6} \mathrm{p}^{3} \mathrm{P}_{2}\right)>n\left(\mathrm{Hg} \mathrm{p}^{3} \mathrm{P}_{0}\right)$ となり $36 \mathrm{~mm}$ 管, $12 \mathrm{~mm}$ 管のもの ${ }^{2,5)}$ と同じ 傾向を示した。

アルゴン準安定原子と水銀原子との Penning 電離による水銀 イオンの生成割合を調べるため改良型吸収法でアルゴン準安定原 子密度を測定した。図7はアルゴン準安定原子密度と Penning 電 離割合の温度 (水銀蒸気圧) 依存性を示す。アルゴン $4 \mathrm{~s}^{3} \mathrm{P}_{2}$ 準安定 原子密度 $n\left(\mathrm{Ar}^{*}\right)$ は管壁温度の増加とともに急激に減少し, $50^{\circ} \mathrm{C}$ 付近で 0 となる.アルゴン $4 \mathrm{~s}^{3} \mathrm{P}_{2}$ 準安定原子と水銀原子との Penning 電離による水銀イオンの生成割合 $K_{\mathrm{p}}$ は次式で与えられる.

$$
K_{\mathrm{p}}=\sigma v n\left(\mathrm{Ar}^{*}\right) n(\mathrm{Hg})
$$

ここで $\sigma$ は Penning 電離断面積, $v$ はアルゴン準安定原子と水銀 原子間の相対速度, $n(\mathrm{Hg})$ は水銀原子密度である。 $\sigma=5.8 \times 10^{-15}$ $\mathrm{cm}^{2}$ の值 ${ }^{13)}$ を用い, 式(11)から計算された $K_{\mathrm{p}}$ を図 7 に示す. Penning 電離割合 $K_{\mathrm{p}}$ は管壁温度 $30^{\circ} \mathrm{C}$ 付近で最大となり, $50^{\circ} \mathrm{C}$ 付近で 0 とな る.したがって $50^{\circ} \mathrm{C}$ 以上で Penning 電離過程による水銀イオンの

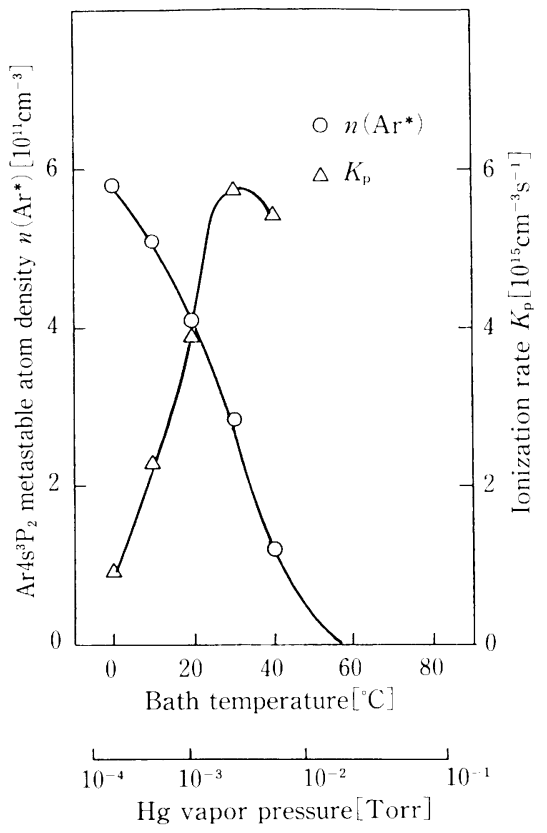

図 7 アルゴン $4 \mathrm{~s}^{3} \mathrm{P}_{2}$ 密度とペニング電離割合の温度（水銀蒸気圧）依存性

Fig. 7 Bath temperature ( $\mathrm{Hg}$ vapor pressure) dependence of the $\operatorname{Ar}(\mathrm{I})$ $4 s^{3} P_{2}$ state density and the Penning ionizetion rate.

生成はほとんど起こらないと思われる。

以上のことから水銀の電離機構を考えると，管壁温度の低温側 では，水銀と電子との電子衝突電離過程とアルゴン準安定原子が 多く存在するため, アルゴン準安定原子と水銀原子との Penning 電離過程が重要となる，高温側では逆に水銀準㚣定原子が多く存 在することから, 水銀潐安定原子と電子との階段電離過程, 水銀 準安定原子同志の衝突による電離過程が重要となる.さらに高温 側では水銀基底イオン密度が飽和する。これは水銀分子イオンの 生成が示され，式(10)の過程も重要となることが考えられる。

\section{4.あとがき}

管径 $4 \mathrm{~mm}$ 液晶バックライト用 $\mathrm{Ar}-\mathrm{Hg}$ プラズマに扔いて, 改 良型吸収法を用い, 水銀イオン密度, 水銀準㚣定原子密度, アル ゴン準安定原子密度を測定した.またシングルプローブ法を用い， 電子温度, 電子密度を測定した。それらの結果から管径の太い一 般の蛍光ランプ $(d=36 \mathrm{~mm})$ と比較して, 細管蛍光ランプのプラズ マの特徴として，以下の結果を得た。

（1）水銀イオン密度と水銀 $6 \mathrm{p}^{3} \mathrm{P}_{0,2}$ 準安走原子密度は管壁温度（水 銀蒸気圧）が高い領域で飽和の傾向を示した。この水銀イオン 密度の飽和は水銀分子イオンの生成を示している。

(2) 電子温度は管壁温度 $0{ }^{\circ} \mathrm{C}$ か $80^{\circ} \mathrm{C}$ の範囲で $2 \mathrm{eV}$ から $1 \mathrm{eV}$ 入と減少し, 電子温度の值は約 2 倍となった。

（3）電子密度の最小を示す管壁温度は高い方へ移行した.

（4）水銀の電離機構を検討した結果，アルゴン準安定原子と水銀 原子との Penning 電離割合は管壁温度 $30^{\circ} \mathrm{C}$ 付近で最大を示し た。

\section{参 考 文 献}

(1) W. Verweij : "Probe Measurements and Determination of Electron Mobility in the Positive Column of Low- 
Pressure Mercury-Argon Discharges”, Philips Res. Rep. Suppl., 2, pp.1-112 (1961).

(2) M. Koedam and A. A. Kruithof: "Transmission of the Visible Mercury Triplet by the Low Pressure MercuryArgon Discharge; Concentration of the $6^{3} \mathrm{P}$ States", Physica, 28, pp.80-100 (1962).

(3) L. Vriens, R. A. J. Keijser and F. A. S. Ligthart : "Ionization processes in the positive column of the LowPressure Hg-Ar discharge", J. Appl. Phys., 49, pp.38073813 (1978).

(4) T. Lin, T. Goto, T. Arai and S. Murayama: " $\mathrm{Hg}^{+}$Ion Density in Low-Pressure Ar-Hg Discharge Used for a Mercury Lamp", J. Appl. Phys., 66, pp.2779-2782 (1989).

(5) T. Lin, T. Goto, T. Arai and S. Murayama : "Measurement of $\mathrm{Hg} 6 \mathrm{p}^{3} \mathrm{P}_{0,1,2}$ State Densities in the Low-Pressure Positive-column Ar-Hg Discharge Using $8 \mathrm{~s}^{3} \mathrm{~S}_{1}-6 \mathrm{p}^{3} \mathrm{P}_{0,1,2}$ Lines”, J. Appl. Phys., 67, pp.4012-4014 (1990).

(6) T. Lin, T. Goto, T. Arai and S. Murayama : "Account of Ionization Mechanism in Low-Pressure Ar-Hg Discharges", J. Appl. Phys., 69, pp.4201-4205 (1991).

（7）渡辺, 林：「管壁負荷一定での $253.7 \mathrm{~nm}$ 光発光効率の管径 ならびに水銀蒸気圧, アルゴン封入圧依存性一 $\mathrm{Ar}-\mathrm{Hg}$ 放電 における253.7nm 光発光効率の管径依存性, その II-」, 照 学誌, 81-2, pp.154-157 (1997).

(8) T. Goto, M. Mori and S. Hattori : "Modified absorption method to determine level population densities in a cataphoresis type of He-metal laser discharge", Appl. Phys. Lett., 29, pp.358-360 (1976).

(9) M. Goto and T. Arai : "Mercury Ion Density in LowPressure Ar-Hg Discharge Plasma Used for Liquid Crystal Display Backlighting", Jpn. J. Appl. Phys., 34, pp.L1074-L1075 (1995).

(10) M. Goto, T. Sakai and T. Arai : "Plasma Parameters in Low-Pressure Ar-Hg Discharge Plasma Used for Liquid Crystal Display Backlighting", Jpn. J. Appl. Phys., 33, pp.L896-L897 (1994).

(11) A. C. G. Michell and M. W. Zemansky : Resonance Radiation and Excited Atoms (Cambriddge Univ. Press, New York 1961).

(12) I. Langmuir and H. M. Mott-Smith : Phys. Rev., 28, p.727 (1926).

(13) D. J. Wren and D. W. Setser : "Quenching Rate Constants of Metastable States of Neon, Argon, and Krypton by Mercury Atoms", J. Chem. Phys., 74, pp.2331 -2338 (1981).

(受付日1998年 8 月 6 日 $/$ 採録日 1999 年 3 月 4 日)

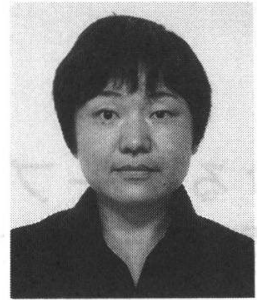

後藤 みき（正会員）

神奈川工科大学電気電子工学科

昭和 30 年 8 月 4 日生まれ. 昭和 54 年 3 月幾 徳工業大学電気工学科卒業. 同年 4 月同大学 助手補, 昭和 62 年同助手, 現在, 大学名改称 L, 神奈川工科大学助手. 応用物理学会, IEEE 会員.

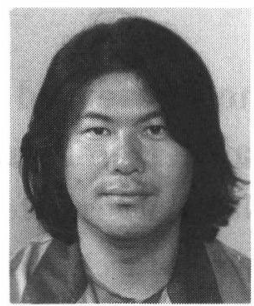

\section{酒井隆行 (非会員)}

沖電気工業侏) (DBG) コンポーネント事業部 生産技術部

昭和 42 年 10 月 7 日生. 平成 5 年 3 月神奈川 工科大学大学院工学研究科修士課程電気工学 専攻修了. 同年 4 月沖電気工業株式会社に入社.

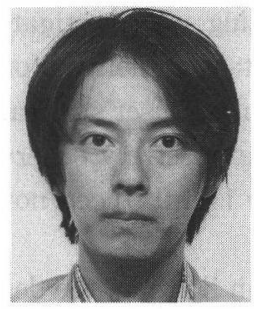

大势签 清 (正会員)

東芝ライテック株式会社技術統括部研究所

昭和 49 年 2 月 21 日生. 平成 10 年 3 月神奈川 工科大学大学院工学研究科博士前期課程電気 工学専攻修了. 現在, 光応用装置の光学設計, 構造設計に関する研究開発業務に従事。

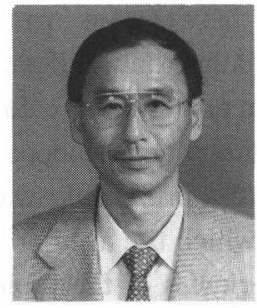

㢣并毞俊彦 (正会員)

神奈川工科大学電気電子工学科

昭和18年12月24日生まれ。昭和54年明治大 学大学院工学研究科博士課程修了. 工学博士. 同年明治大学助手. 昭和 58 年幾徳工業大学 (現 神奈川工科大学) 講師, 助教授を経て, 昭和63年より同教授. フ ラズマプロセス, レーザ分光計測, 光源プラズマの研究に従事. 応用物理学会会員. 